\title{
Integrated Planning of Timber Extraction and Hauling Activities by using Network 2000 Program*
}

\author{
Abdullah E. Akay*(iD), Nedimcan Şeşen \\ Bursa Technical University, Faculty of Forestry, 16310 Bursa, Turkey
}

\begin{abstract}
Planning of forest transportation is a complex problem that requires effective and harmonious design and implementation of various forest operations including extraction, loading, and hauling of forest products. These operations constitute a significant part of the total cost of producing forest products; therefore, developing the most appropriate (minimum cost/maximum net profit) transportation plan has increasing importance for the economic aspect. Computer-aided models can be used to plan the transportation of forest products and systematically searching for the most suitable solution. In this study, a network analysis-based Network 2000 program was used to determine the optimum routes with minimum forest operation costs and maximum net profit of forest products considering two logging truck types (medium and large size). In the solution process, two farm tractors (4x2 and $4 \times 4$ ) for extraction operation and two loaders (tracked and rubber-tired) for loading operation were evaluated. The alternative with the minimum cost was determined using the Network 2000 program. The study was implemented in Kınık Forest Enterprise Chief (FEC) located in the city of Bursa in Turkey, while considering five landing areas where various forest products (i.e. $\log$, mine poles, industrial wood, and paper wood) were extracted from the six harvesting units and hauled to two forest depots. In the study, the optimum solution was searched for two scenarios where only the forest depot which is commonly used in the Kınık FEC was considered in the first scenario while the forest depot of the neighboring enterprise in the region was also evaluated in the second scenario. The results obtained from the first scenario indicated that using large-size tractor reduced the hauling cost by $8 \%$ which led to over 1000 TRY reduction in the total cost of forest operations. The hauling cost and total forest operation cost obtained in the second scenario was about $16 \%$ and $2 \%$ less than that of the cost obtained in the first scenario for the case of large-size truck. On the other hand, total net profit of the forest products received in the second scenario was about 35000 TRY more than that of the net profit received in the first scenario for the case of large-size truck. The optimum farm tractor for skidding operation was successfully selected by the Network 2000 program considering terrain conditions in the harvesting unit and availability of the equipment. Likewise, optimum loader was also determined by considering distribution of the forest products on the landing areas.
\end{abstract}

Keywords: Forest operations, skidding, loading, hauling, least cost, network analysis.

\section{Introduction}

Harvesting process of wood-based forest products involves various stages including cutting and felling, delimbing, bucking, logging, loading, hauling, unloading and stacking (Eker and Acar, 2006). These stages are conducted by implementing different techniques and methods that are being developed day by day in order to reduce the cost, simplify the work and use the time efficiently (Coşkun et al., 2010). The logging operation, defined as the transportation of wood-based forest products from the woods to the landing area at the roadside, is a cost-intensive and time-consuming stage of forest harvesting. In forested lands with steep ground slope and insufficient road network, the cost of timber logging operation increases even more.

The timber logging is followed by the loading operation which has an important function in hauling forest products without any excessive delays. The loading efficiency depends on good coordination between the loading operation and felling, logging, and hauling operations. The timber hauling following the loading stage constitutes about $40 \%$ of the total production costs of forest products (Acar, 1998). In forest harvesting, hauling is an important stage that completes the logging operation. In general, logging trucks in various sizes are used to haul timber from landing to forest depots (Acar and Eroğlu, 2001). The most important factors affecting the cost of hauling include loading capacity and hourly cost of the logging truck, and road features (i.e. gradient, length, type and condition).

Traditional methods, which are mainly based on the experience of the planner, are insufficient in selecting the most appropriate logging methods and developing the 
hauling plan. On the other hand, significant savings can be achieved in terms of time and economy by implementing computer-aided approaches in decisionmaking process of these stages. Advances in computer technology and modern mathematical algorithms helped decision-makers develop alternative methods for solving forest transportation problems (Sessions et al., 2001). Network 2000 program, developed by Chung and Sessions (2001), has been widely used to solve the lowest costs problems in various forestry operations worldwide, particularly in the Pacific North West region in the USA (Akay et al., 2021).

In this study, the Network 2000 program was used to determine the optimum forest transportation routes with minimum hauling cost and maximum net profit for two scenarios. In the first scenario, forest products were hauled from landing areas to the commonly used forest depot in the Kınık FEC, while another forest depot located in the region was also integrated into the forest transportation plan. In the solution phase, optimum routes for hauling forest products from the specified landing areas to the forest depots were determined considering two logging truck types. In the application, two farm tractors were evaluated in extracting forest products and two loaders were evaluated in loading them into logging trucks.

\section{Material and Methods \\ 2.1. Study Area}

The study area is located in Kinık Forestry Enterprise Chief (FEC) of Orhaneli Forestry Enterprise Directorate (FED) in the border of Bursa Forestry Regional Directorate. In the study, four types of forest products (i.e., log, mine poles, industrial wood, and paper wood) were extracted from six harvesting units, dominated with black pine (Pinus nigra). These forest products were skidded to five landing areas in Kınık FEC. While the forest products are commonly hauled to the forest depot of Büyükorhan Enterprise Chief, another depot in the neighboring FEC of Harmancik was also considered in the study. If FECs agree, the forest products can be stacked and sold out by the depot of another enterprise. The current data about the forest products (i.e. product type, volume, unit price), landing locations (i.e. Ln 1-Ln 5 ), and road networks were obtained from the Orhaneli FED. Figure 1 indicates the location of the Kinık FEC and land use types in the study area. The road networks for Kınık FEC and neighboring FECs, Büyükorhan and Harmancik Forest Depots, and landing areas can be seen in Figure 2. The road network layer has the necessary data about each road section, including road types (asphalt, gravel, forest road), and road conditions (good, medium, poor).

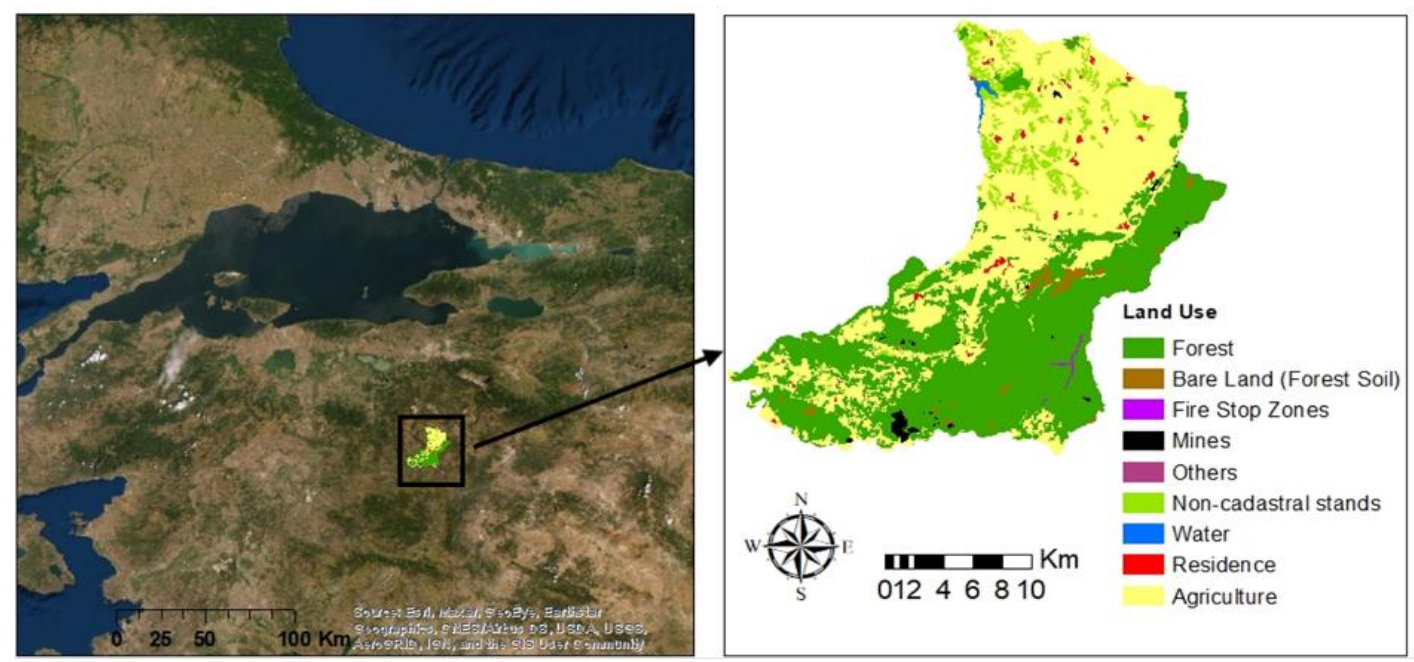

Figure 1. Study area

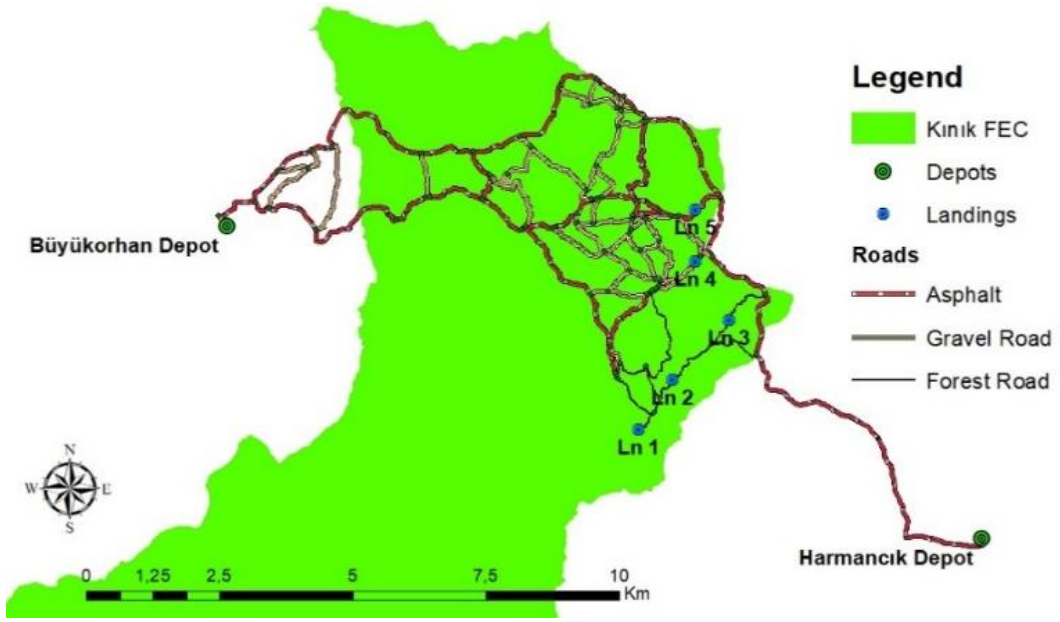

Figure 2. Data Layers of the study area 


\subsection{Forest Operations}

In this study, the forest operations including skidding, loading, and hauling were evaluated considering alternative equipment in each operation. Two types of farm tractors, including $4 \times 2$ drive (Universal $445 \mathrm{~S}$ ) and $4 \times 4$ drive (New Holland TT55B) tractors, were used during the extraction of forest products in the region (Figure 3). In this study, $4 \times 2$ tractor was limited to a ground slope of more than $20 \%$, while $4 \times 4$ tractor was able to operate up to $40 \%$ slope. The forest products were loaded onto the logging trucks using the tracked loader (Sumitomo SH135) and rubber-tired loader (New Holland TD 90D) in the region (Figure 4). Tracked loader is preferred when the forest products are piled close to each other in the landing area due to limited mobility features, while a rubbertired loader with higher mobility capability is not limited with the distribution of the forest products. For timber hauling activity, two common logging trucks including BMC Pro 522 (15 tons) and Mercedes-Benz Axor 1840 LS (22 tons) were evaluated in the study (Figure 5).
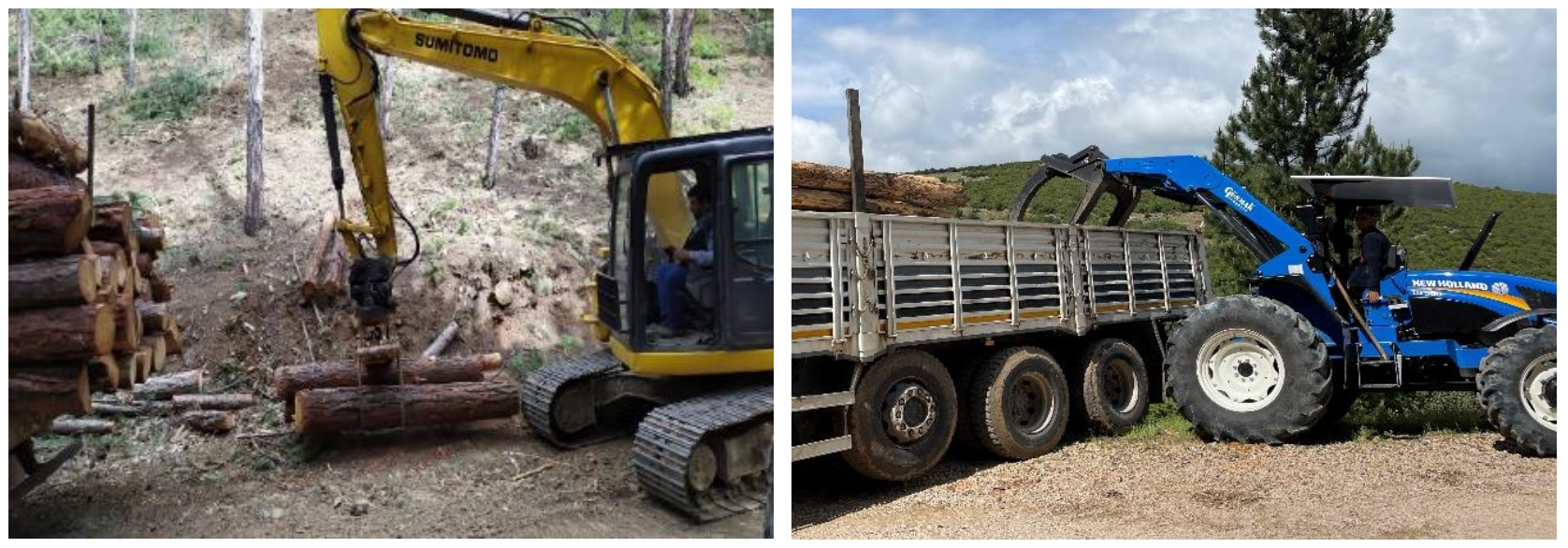

Figure 3. Loading operation with tracked loader (Sumitomo SH135) (left) and rubber-tired loader (New Holland TD 90D) (right)
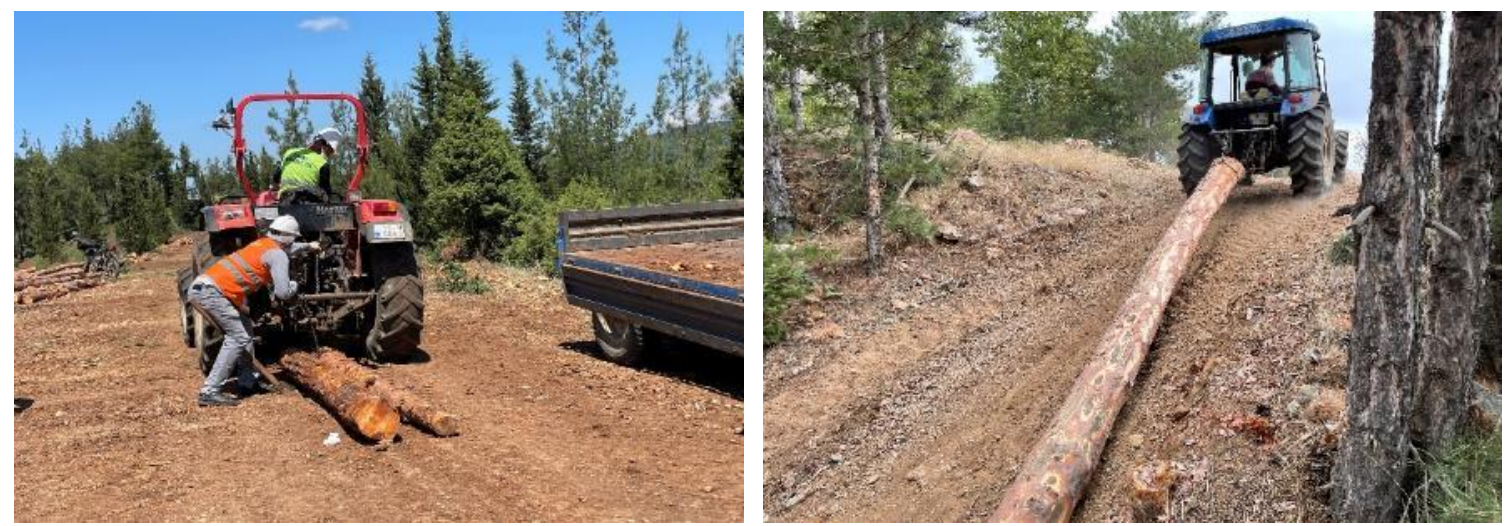

Figure 4. Skidding with Universal 445S (left) and New Holland TT55B (right) farm tractors
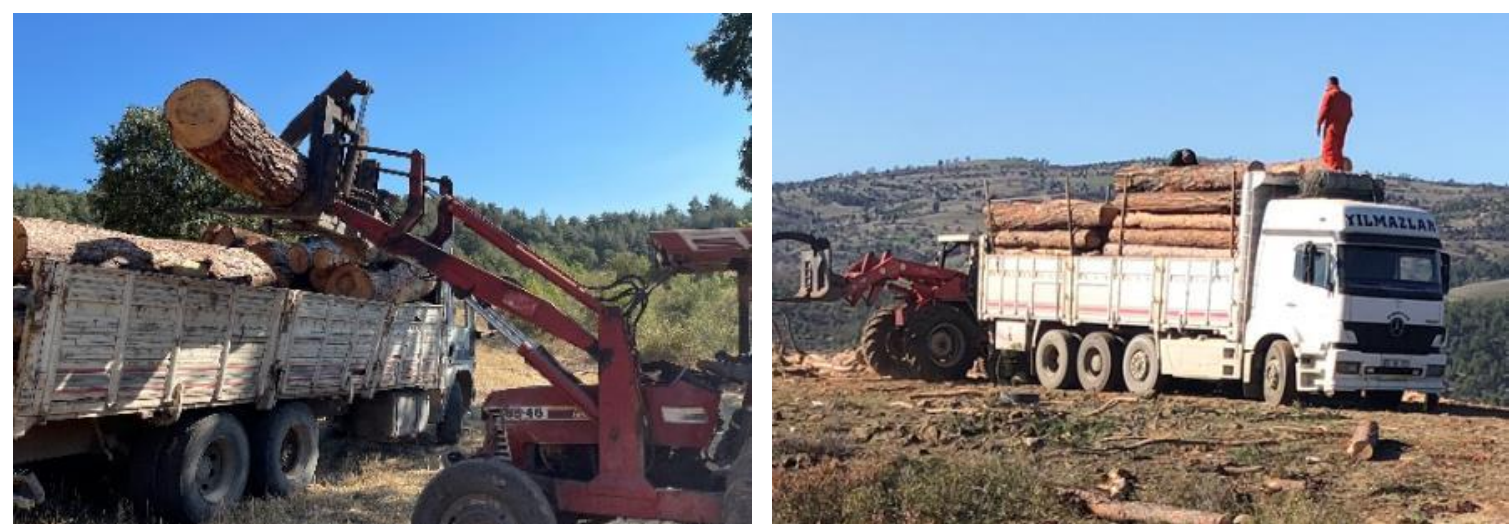

Figure 5. Hauling operation with BMC Pro 522 medium-size truck (left) and Mercedes-Benz Axor 1840 LS model large-size truck (right) 
The terrain condition of the harvesting units and distribution of the forest products in the landing areas were observed in the field (Table 1). It was seen that ground slope was over $20 \%$ in harvesting units of 120 , 89,91 , and 25 in which $4 \times 4$ farm tractor was allowed for skidding operation. In unit $64,4 \times 2$ farm tractor was preselected for the skidding as contractor company working in this unit did not have $4 \times 4$ tractor. In landing 2 and 5, rubber-tired loader was preferred since the forest products were not piled close to each other in these landing areas.

\subsection{The Unit Cost Data}

The unit cost $(\mathrm{TL} / \mathrm{m} 3)$ of the equipment used in skidding and loading activities were obtained from the Orhaneli FED. Table 2 indicates the unit cost of skidding for farm tractors with respect to product types. It was reported that unit cost of skidding mine poles was slightly greater than that of other products. The unit cost of loading operation was $10.58 \mathrm{TRY} / \mathrm{m}^{3}$ and 13.27 $\mathrm{TRY} / \mathrm{m}^{3}$ for tracked loader and rubber-tired loader, respectively.

Table 1. Summary data about the harvesting unit and landing areas

\begin{tabular}{cccccc}
\hline $\begin{array}{c}\text { Harvesting } \\
\text { Units }\end{array}$ & $\begin{array}{c}\text { Landing } \\
\text { Areas }\end{array}$ & $\begin{array}{c}\text { Ground } \\
\text { Slope }(\%)\end{array}$ & $\begin{array}{c}\text { Distribution of the } \\
\text { Forest Products }\end{array}$ & $\begin{array}{c}\text { Farm } \\
\text { Tractor }\end{array}$ & Loader \\
\hline 120 & Ln 1 & 25 & Accumulated & $4 \times 4$ & Tracked \\
89 and 91 & Ln 2 & 32 and 35 & Not Accumulated & $4 \times 4$ & Rubber-tired \\
64 & Ln 3 & 20 & Accumulated & $4 \times 2 *$ & Tracked \\
38 & Ln 4 & 18 & Accumulated & $4 \times 2$ or $4 \times 4$ & Tracked \\
25 & Ln 5 & 35 & Not Accumulated & $4 \times 4$ & Rubber-tired \\
\hline
\end{tabular}

* 4x4 farm tractor was presumably not available in landing $3(\operatorname{Ln} 3)$

Table 2. The unit cost $\left(\mathrm{TRY} / \mathrm{m}^{3}\right)$ of skidding operations*

\begin{tabular}{lcc}
\hline Forest Products & $4 \times 2$ Farm Tractor & $4 \times 4$ Farm Tractor \\
\hline Log $(\mathrm{L})$ & 29.88 & 23.22 \\
Mine poles (MP) & 35.86 & 27.86 \\
Industrial wood (IW) & 29.88 & 23.22 \\
Paper wood (PW) & 29.88 & 23.22 \\
\hline * TRY (Turkish Lira) $\approx 0.10$ Euro at the time of study (September 2021)
\end{tabular}

The unit cost of hauling (TRY/m $\mathrm{m}^{3}$ ) for each road section was computed based on the hourly unit cost of the logging truck (TRY /hour), load capacity of the truck $\left(\mathrm{m}^{3}\right)$ and truck operating time (hours) on each road section (Akay et al., 2021):

$$
\begin{aligned}
& T C=H C /((L C / t)) \\
& T C=\text { unit cost hauling }\left(\mathrm{TRY} / \mathrm{m}^{3}\right) \\
& H C=\text { hourly unit cost of the truck (TRY/hour) } \\
& L C=\text { load capacity }\left(\mathrm{m}^{3}\right) \\
& t=\text { round trip truck operating time (hours) }
\end{aligned}
$$

Based on the information obtained from the local forest sector, the hourly unit cost of logging truck was estimated as $65.60 \mathrm{TRY} /$ hour and $89.02 \mathrm{TRY} /$ hour for the medium (15 tons) and large (22 tons) size trucks, respectively. The round trip operating time $(t)$ was computed based on road length $(\mathrm{km})$, truck speed $(\mathrm{km} /$ hour), and estimated delay time (Akay et al., 2021):

$t=2 L(1+D T) / V$

$L=$ road length per section $(\mathrm{km})$

$V=$ average truck speed $(\mathrm{km} / \mathrm{hour})$

$D T=$ delay time (asphalt: $5 \%$, gravel: $10 \%$, forest road: $15 \%$ )

The average truck speed was assigned to each road section considering the road types and road conditions based on the previous studies and interviews with local expert drivers (Akay et al., 2021) (Table 3). The truck speed is the average of the loaded truck and unloaded truck speed.

Table 3. The average truck speed ( $\mathrm{km} /$ hour) with respect to road types and conditions

\begin{tabular}{lccc}
\hline \multirow{2}{*}{ Road Type } & \multicolumn{3}{c}{ Road Conditions } \\
\cline { 2 - 4 } & Good & Medium & Poor \\
\hline Asphalt & 60 & 50 & 40 \\
Gravel & 40 & 30 & 20 \\
Forest road & 25 & 20 & 15 \\
\hline
\end{tabular}




\subsection{Forest Products Data}

The amount of forest products $\left(\mathrm{m}^{3}\right)$ delivered to landing areas (i.e. $\operatorname{Ln} 1-\operatorname{Ln} 5$ ) and the most recent average unit sales prices $\left(\mathrm{TRY} / \mathrm{m}^{3}\right)$ of the forest products in two forest depots were obtained from the Orhaneli FED during the study. Table 4 indicates the amount of forest products extracted from the harvesting unit and delivered to the landing areas. The average unit sale prices of the forest products for Büyükorhan and Harmanc1k depots are listed in Table 5.

Table 4. The amount of forest products $\left(\mathrm{m}^{3}\right)$ delivered to landing areas

\begin{tabular}{cccccc}
\hline $\begin{array}{c}\text { Harvesting } \\
\text { Units }\end{array}$ & $\begin{array}{c}\text { Landing } \\
\text { Areas }\end{array}$ & Log & Mine poles & Industrial wood & Paper wood \\
\hline 120 & Ln 1 & 403.24 & 121.81 & 0.00 & 181.46 \\
89 and 91 & Ln 2 & 460.66 & 232.18 & 11.39 & 250.66 \\
64 & Ln 3 & 208.06 & 194.61 & 1.12 & 48.85 \\
38 & Ln 4 & 73.21 & 35.91 & 0.00 & 20.74 \\
25 & Ln 5 & 357.36 & 123.31 & 7.99 & 130.26 \\
\hline
\end{tabular}

Table 5. The average unit sale prices $\left(\mathrm{TRY} / \mathrm{m}^{3}\right)$ of the forest products

\begin{tabular}{lcccc}
\hline Forest Depots & Log & Mine poles & Industrial wood & Paper wood \\
\hline Büyükorhan (BD) & 1105 & 783 & 623 & 683 \\
Harmanc1k (HD) & 1088 & 831 & 645 & 595 \\
\hline
\end{tabular}

\subsection{Network Analysis}

In this study, the optimum routes with minimum hauling cost and maximum net profit was determined by using the Network 2000 program. In this program, criteria such as alternative logging techniques, forest depots, different forest products, alternative routes, the

least cost and the highest net profit can be taken into account (Akay and Erdaş, 2007). The network database is composed of the links and the nodes where the links intersect. The program has two data input tables including "Link Editor" and "Sale Editor" (Figure 6).

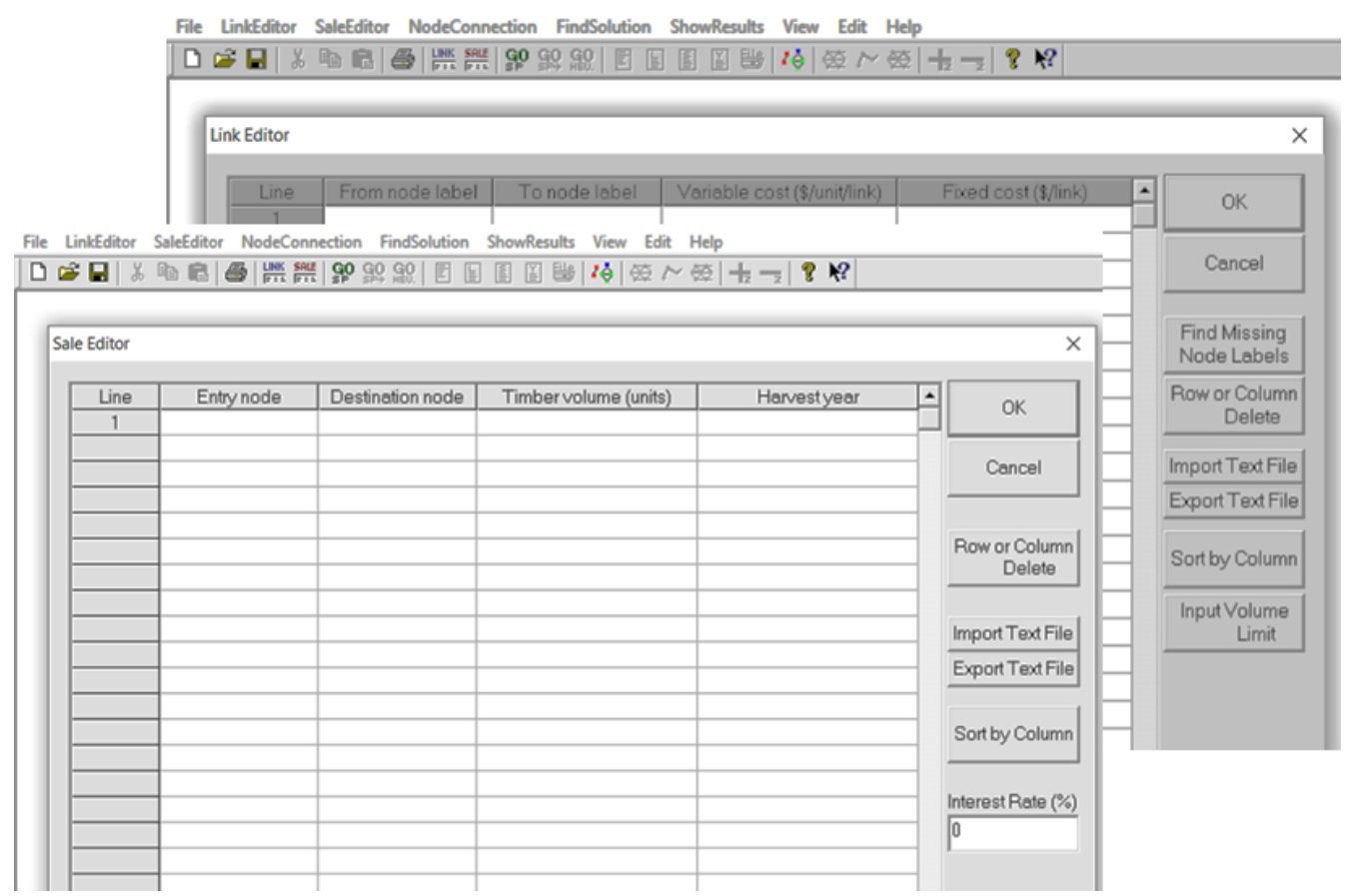

Figure 6. "Link Editor" and "Sale Editor" in Network 2000 program

In the network system from landing areas to forest depots, the links represent the road sections. In "Link Editor", the beginning node of the road section is entered in "From Node Label" column and the ending node is entered in "To Node Label" column. The value of each link (road section) represents the unit cost of hauling forest products $\left(\mathrm{TRY} / \mathrm{m}^{3}\right)$, which is entered in "Variable
Cost" column in "Link Editor". It is assumed that the route to be followed by the empty truck will be the same as the route followed by the loaded truck. Thus, the unit cost of hauling refers to the total unit cost of a logging truck travelling loaded on a specified road section and travelling back empty on the same road section (Equation 1). If there is a construction or maintenance 
activities on the road section, the cost of these activities are defined as fixed costs and entered in the "Fixed Cost" column in "Link Editor". In order to include the fixed cost in the system, the fixed cost value is divided by the volume of the forest product transported on the link (road section) and converted into equivalent variable cost $\left(\mathrm{TRY} / \mathrm{m}^{3}\right)$. In this study, separate "Link Editor" was generated for each truck alternative to evaluate the effects of using different logging trucks (medium and large) on total hauling cost.

In the network system from harvesting unit to landing areas, links represents the cost of the forest operations including tractor skidding and loading of the forest products (Figure 7). Two farm tractors, including $4 \times 2$ drive (New Holland TT55) and 4x4 drive (New Holland TD65) tractors, were considered for the extraction of forest products in the region. To restrict the usage of $4 \times 2$ farm tractor for the harvesting units (i.e. 25, 89, 91 and 120 ) with slope of over $20 \%$, penalty cost of 10000 TRY was assigned to the specified link. Besides, $4 \times 4$ farm tractor was restricted with penalty cost in harvesting unit 25 as it was presumed that it was not available. For loading of forest products onto the logging trucks, two alternative loaders of tracked (TL) and rubber-tired loader (RL) were considered in the study. Since the tracked loader is not effective when the forest products are not piled together in the landing, the penalty cost was assigned to the specified links on landing 2 and 5 .

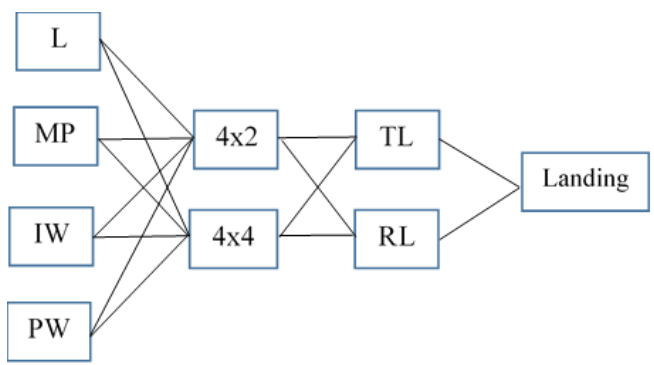

Figure 7. Network system indicating forest products and alternative forest equipment

The forest products extracted from Kınık FEC are regularly hauled to Büyükorhan forest depot; however, another depot (Harmancik) is also located in the neighboring FEC in the region. Since the unit sale prices of the forest products are different in two forest depots, the optimum hauling routes with minimum hauling cost and maximum net profit was searched for two scenarios. In the first scenario, forest products were hauled to only Büyükorhan forest depot, while both forest depots were permitted in the second scenario. In the part of network system representing forest depots, links represent the unit sale prices of the forest products (Figure 8). Since Network 2000 program is developed to minimize costs, the unit cost of hauling forest products were entered into the network database as positive values while unit sale prices of the forest products as negative values. The optimum route, which minimized the sum of the total value of costs and sale prices (total value $<0$ as unit sale price $>$ unit costs) in the network system, will provide the maximum the net profit considering absolute of the total value.

In Network 2000 program, first node and last node for each forest product was specified under "Entry node" and "Destination node" columns, respectively, in the "Sale Editor". Besides, the total amount of each forest product $\left(\mathrm{m}^{3}\right)$ was entered under "Timber volume" column. Network 2000 is able to compute net present value of forest products for various time periods by defining the interest rate and harvesting year at "Sale Editor". In this study, the interest rate and harvesting year was not defined as the planning of skidding, loading and hauling was aimed to be developed for the year of 2021. The felling operation was not included in the analysis.

\section{Results and Discussion}

Network 2000 program was used to determine the optimum routes that minimize the hauling cost and maximize the net profit of forest products considering two logging truck with different load capacities (medium and large). The program was run for two scenarios in which forest products were hauled to the only commonly used forest depot in the first scenario, while second scenario includes both commonly used forest depot and another forest depot located in the region. In the study, tractor skidding and loading was also evaluated by using Network 2000.

\subsection{Skidding and Loading Costs}

The least cost equipment for skidding and loading operations were searched by considering topography, the distribution of the forest products, and availability. The results indicated that optimum equipment selection minimized the tractor skidding cost and loading cost as 73033.76 TRY and 34521.92 TRY, respectively (Table 6). It was found that the skidding operation with the minimum cost took place in harvesting unit 38 , followed by unit 64 , where $4 \times 4$ tractor was used in both. The minimum loading cost was recorded in landing 4, followed by landing 3 . On the other hand, the maximum skidding cost was in harvesting unit combination of 89 and 91 where $4 \times 2$ tractors were operating, while the loading cost was maximized in landing 2 . The total cost of extraction (i.e., skidding and loading) was minimized in the combination of harvesting unit 38 and landing 4. It was found that maximum extraction cost was recorded in the combination of harvesting units 89-91 and landing 4. 


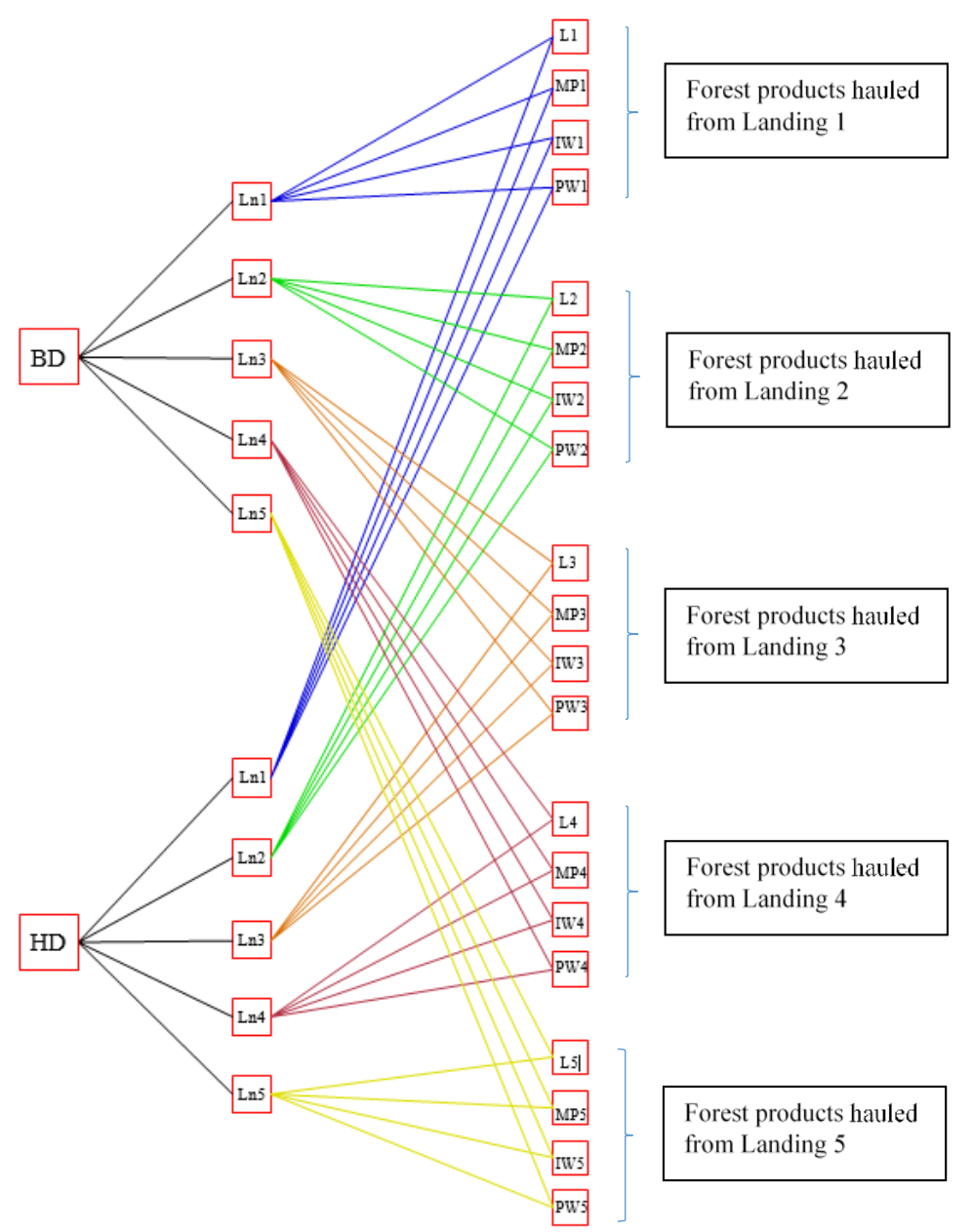

Figure 8. Network system indicating forest depots and last node of forest products

Table 6. Cost summary of skidding and loading operations

\begin{tabular}{ccccc}
\hline $\begin{array}{c}\text { Harvesting } \\
\text { Units }\end{array}$ & $\begin{array}{c}\text { Landing } \\
\text { Areas }\end{array}$ & $\begin{array}{c}\text { Skidding Cost } \\
\text { (TRY) }\end{array}$ & $\begin{array}{c}\text { Loading Cost } \\
\text { (TRY) }\end{array}$ & $\begin{array}{c}\text { Extraction } \\
\text { Cost (TRY) }\end{array}$ \\
\hline 120 & Ln 1 & 16970.42 & 7474.91 & 24445.33 \\
89 and 91 & Ln 2 & 23249.80 & 12671.35 & 35921.15 \\
64 & Ln 3 & 14688.51 & 4788.89 & 19477.40 \\
38 & Ln 4 & 3181.75 & 1373.82 & 4555.57 \\
25 & Ln 5 & 14943.28 & 8212.95 & 23156.23 \\
\hline
\end{tabular}

Tables 7 and 8 indicates the skidding and loading costs, respectively, for forest products types. The results revealed that the most cost-intensive skidding operation was extracting logs from the woods to landing area. The skidding of all forest products, except mine pole, from harvesting unit combination of 89 and 91 to landing 2 was the most expensive operation among other units. For the loading operation, most cost-intensive operation was again loading logs among other products and the most expensive loading took place in landing 2 for each product type. The optimum solution of the skidding and loading operations was the same for the hauling truck alternatives and forest depot scenarios.

Table 7. The costs of skidding operation concerning forest products

\begin{tabular}{cccccc}
\hline Harvesting Units & $\begin{array}{c}\text { Landing } \\
\text { Areas }\end{array}$ & $\begin{array}{c}\text { Log } \\
(\text { TRY })\end{array}$ & $\begin{array}{c}\text { Mine pole } \\
(\text { TRY })\end{array}$ & $\begin{array}{c}\text { Industrial wood } \\
(\text { TRY })\end{array}$ & Paper wood (TRY) \\
\hline 120 & Ln 1 & 9363.28 & 3393.57 & 0.00 & 4213.57 \\
89 and 91 & Ln 2 & 10696.50 & 6468.59 & 264.36 & 5820.35 \\
64 & Ln 3 & 6216.86 & 6978.61 & 33.44 & 1459.61 \\
38 & Ln 4 & 1699.89 & 1000.37 & 0.00 & 481.49 \\
25 & Ln 5 & 8297.83 & 3435.44 & 185.41 & 3024.59 \\
\hline
\end{tabular}


Akay and Şeşen

Table 8 . The costs of loading operation with respect to forest products

\begin{tabular}{cccccc}
\hline Harvesting Units & $\begin{array}{c}\text { Landing } \\
\text { Areas }\end{array}$ & $\begin{array}{c}\text { Log } \\
(\text { TRY })\end{array}$ & $\begin{array}{c}\text { Mine pole } \\
(\text { TRY })\end{array}$ & $\begin{array}{c}\text { Industrial wood } \\
(\text { TRY) }\end{array}$ & Paper wood (TRY) \\
\hline 120 & Ln 1 & 4266.30 & 1288.73 & 0.00 & 1919.88 \\
89 and 91 & Ln 2 & 6112.94 & 3081.06 & 151.08 & 3326.27 \\
64 & Ln 3 & 2201.29 & 2058.94 & 11.84 & 516.82 \\
38 & Ln 4 & 774.54 & 379.90 & 0.00 & 219.39 \\
25 & Ln 5 & 4742.13 & 1636.34 & 105.96 & 1728.52 \\
\hline
\end{tabular}

\subsection{Minimum Hauling Cost}

\subsubsection{Scenario I}

In the first scenario, the optimum transportation plan that minimized the cost of hauling forest products was developed for the medium-size (15 ton) and large-size (22 ton) logging trucks considering only Büyükorhan depot in the region. For each landing area, the hauling cost was computed by subtracting the extraction costs (skidding plus loading costs) of the associated harvesting unit and landing from the total cost provided by the Network 2000 program. The total hauling cost was estimated as 12977.04 TRY for the case of medium-size truck, while it was reduced to 119531.64 TRY for largesize truck (Table 9). Utilizing a large logging trucks with high load capacity increases the hauling cost, which leads to a reduction in total hauling cost (Akay et al., 2021).

Table 9. The cost summary of hauling operations and total costs for the first scenario

\begin{tabular}{cccccc}
\hline Harvesting & Landing & \multicolumn{2}{c}{ Medium-size Truck (TRY) } & \multicolumn{2}{c}{ Large-size Truck (TRY) } \\
\cline { 3 - 5 } Units & Areas & Total Costs & Hauling Cost & Total Costs & Hauling Cost \\
\hline 120 & Ln 1 & 27645.73 & 3200.40 & 27398.44 & 2953.11 \\
89 and 91 & Ln 2 & 40600.22 & 4679.07 & 40237.36 & 4316.21 \\
64 & Ln 3 & 21958,05 & 2480.65 & 21763.41 & 2286.01 \\
38 & Ln 4 & 5074.03 & 518.46 & 5032.48 & 476.91 \\
25 & Ln 5 & 25254.69 & 2098.46 & 25099.95 & 1943.72 \\
\hline
\end{tabular}

It was also found that the hauling of forest products from harvesting unit combination of 89 and 91 to landing 2 was the most expensive operation among others for both truck types. On the other hand, the hauling cost of forest products, except industrial wood, was minimized at the combination of unit 38 and landing 4 (Table 10,
11). The maps of optimum hauling routes were generated in ArcGIS 10.4.1 program for both logging trucks. Figure 9 indicates that both logging trucks followed the same route to minimize the cost of hauling forest products for each landing area.

Table 10. The cost of hauling forest products for medium-size truck in the first scenario

\begin{tabular}{cccccc}
\hline \multirow{2}{*}{ Harvesting Units } & $\begin{array}{c}\text { Landing } \\
\text { Areas }\end{array}$ & $\begin{array}{c}\text { Log } \\
\text { (TRY) }\end{array}$ & $\begin{array}{c}\text { Mine pole } \\
\text { (TRY) }\end{array}$ & $\begin{array}{c}\text { Industrial wood } \\
\text { (TRY) }\end{array}$ & Paper wood (TRY) \\
\hline 120 & Ln 1 & 1826.61 & 551.88 & 0.00 & 821.91 \\
89 and 91 & Ln 2 & 2257.27 & 1137.60 & 55.99 & 1228.20 \\
64 & Ln 3 & 1140.13 & 1066.60 & 6.18 & 267.74 \\
38 & Ln 4 & 292.18 & 143.39 & 0.00 & 82.88 \\
25 & Ln 5 & 1211.56 & 417.98 & 27.27 & 441.66 \\
\hline
\end{tabular}

Table 11. The cost of hauling forest products for large-size truck in the first scenario

\begin{tabular}{cccccc}
\hline \multirow{2}{*}{ Harvesting Units } & $\begin{array}{c}\text { Landing } \\
\text { Areas }\end{array}$ & $\begin{array}{c}\text { Log } \\
(\text { TRY) }\end{array}$ & $\begin{array}{c}\text { Mine pole } \\
(\text { TRY) }\end{array}$ & $\begin{array}{c}\text { Industrial wood } \\
(\text { TRY) }\end{array}$ & Paper wood (TRY) \\
\hline 120 & Ln 1 & 1685.47 & 509.24 & 0.00 & 758.40 \\
89 and 91 & Ln 2 & 2082.22 & 1049.37 & 51.66 & 1132.95 \\
64 & Ln 3 & 1050.66 & 982.92 & 5.70 & 246.73 \\
38 & Ln 4 & 268.75 & 131.90 & 0.00 & 76.25 \\
25 & Ln 5 & 1122.22 & 387.15 & 25.27 & 409.09 \\
\hline
\end{tabular}



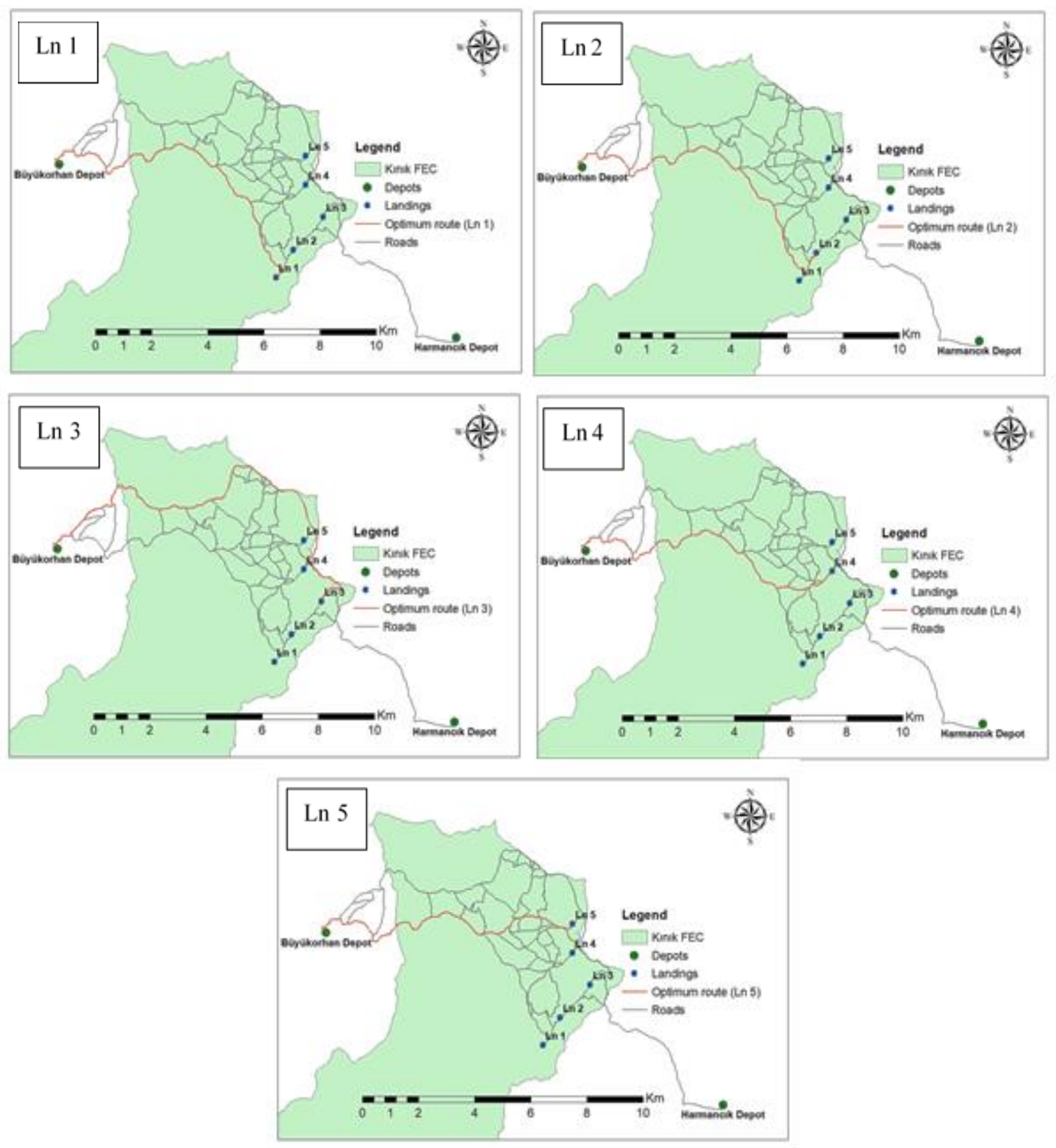

Figure 9. Optimum hauling routes for both logging trucks in the first scenario

\subsubsection{Scenario II}

In the second scenario, the optimum transportation plan that minimized the cost of hauling forest products was developed for both logging trucks considering not only Büyükorhan depot but also Harmancik depot in the region. The total hauling cost was estimated as 10928.22 TRY for the case of medium-size truck, while it was reduced to 10097.59 TRY for large-size truck (Table 12). The results indicated that forest products were hauled to different forest depots, except landing 1, compared to the results from the first scenario. It was found that the hauling cost and total forest operation cost obtained in the second scenario was about $16 \%$ and $2 \%$ less than that of the cost obtained in the first scenario for the case of large-size truck. On the other hand, total net profit of the forest products earned in the second scenario was about 35000 TRY, which is more than that of the net profit earned in the first scenario for the case of large-size truck. 
Table 12. The cost summary of hauling operations and total costs for the second scenario

\begin{tabular}{|c|c|c|c|c|c|}
\hline \multirow{2}{*}{$\begin{array}{c}\text { Harvesting } \\
\text { Units }\end{array}$} & \multirow{2}{*}{$\begin{array}{c}\text { Landing } \\
\text { Areas }\end{array}$} & \multicolumn{2}{|c|}{ Medium-size truck (TRY) } & \multicolumn{2}{|c|}{ Large-size truck (TRY) } \\
\hline & & Total Costs & Hauling Cost & Total Costs & Hauling Cost \\
\hline 120 & $\operatorname{Ln} 1$ & 27645.73 & 3200.40 & 27398.44 & 2953.11 \\
\hline 89 and 91 & $\operatorname{Ln} 2$ & 39950.89 & 4029.74 & 39654.87 & 3733.72 \\
\hline 64 & $\operatorname{Ln} 3$ & 21007,5 & 1530.10 & 20889.81 & 1412.41 \\
\hline 38 & $\operatorname{Ln} 4$ & 4897.42 & 341.85 & 4870.15 & 314.58 \\
\hline 25 & Ln 5 & 24982.36 & 1826.13 & 24840.00 & 1683.77 \\
\hline
\end{tabular}

According to forest product types, maximum and minimum hauling cost for both logging truck types took place in the same harvesting units and landing recorded for the first scenario (Table 13, 14). It was also found that the forest products at landing 1 were hauled to Büyükorhan forest depot, while forest products from other landing areas were hauled to Harmancik depot for both trucks. In this scenario, the forest products from landing 1 was hauled to Büyükorhan depot while the forest products from other four depots were hauled to Harmancik depot. This result revealed that considering alternative forest depots other than the using only one depot in the FECs can help to minimize total hauling costs (Akay and Erdaş, 2007). For both logging trucks, the optimum route that minimized the cost of hauling forest products was the same for each landing area (Figure 10).

Table 13. The cost of hauling forest products for medium-size truck in the second scenario

\begin{tabular}{cccccc}
\hline \multirow{2}{*}{ Harvesting Units } & $\begin{array}{c}\text { Landing } \\
\text { Areas }\end{array}$ & $\begin{array}{c}\text { Log } \\
(\text { TRY })\end{array}$ & $\begin{array}{c}\text { Mine pole } \\
(\text { TRY) }\end{array}$ & $\begin{array}{c}\text { Industrial wood } \\
\text { (TRY) }\end{array}$ & Paper wood (TRY) \\
\hline 120 & Ln 1 & 1826.61 & 551.88 & 0.00 & 821.91 \\
89 and 91 & Ln 2 & 1944.02 & 979.71 & 48.25 & 1057.75 \\
64 & Ln 3 & 703.20 & 657.92 & 3.83 & 165.15 \\
38 & Ln 4 & 192.61 & 94.55 & 0.00 & 54.68 \\
25 & Ln 5 & 1054.32 & 363.72 & 23.76 & 384.34 \\
\hline
\end{tabular}

Table 14. The cost of hauling forest products for large-size truck in the second scenario

\begin{tabular}{cccccc}
\hline \multirow{2}{*}{ Harvesting Units } & $\begin{array}{c}\text { Landing } \\
\text { Areas }\end{array}$ & $\begin{array}{c}\text { Log } \\
\text { (TRY) }\end{array}$ & $\begin{array}{c}\text { Mine pole } \\
\text { (TRY) }\end{array}$ & $\begin{array}{c}\text { Industrial wood } \\
\text { (TRY) }\end{array}$ & Paper wood (TRY) \\
\hline 120 & Ln 1 & 1685.47 & 509.24 & 0.00 & 758.40 \\
89 and 91 & Ln 2 & 1801.21 & 907.74 & 44.72 & 980.04 \\
64 & Ln 3 & 649.10 & 607.32 & 3.54 & 152.45 \\
38 & Ln 4 & 177.24 & 87.01 & 0.00 & 50.32 \\
25 & Ln 5 & 972.12 & 335.36 & 21.92 & 354.38 \\
\hline
\end{tabular}

\subsection{Total Net Profit}

\subsubsection{Scenario I}

In the first scenario, the optimum transportation plan that maximized the total net profit of forest products was developed for both logging trucks considering only Büyükorhan depot. The total net profit was estimated as 2538392.99 TRY for the case of medium-size truck, while it was slightly increased up to 2539394.05 TRY for large-size truck (Table 15). Then, the hauling cost was computed by subtracting net profit and extraction cost (i.e. skidding plus loading) of forest products from the total sale price. Since there is only one forest depot in the network analysis, the hauling cost and hauling route was the same as the results obtained for the minimum hauling cost presented in the previous section for both truck types.

The main reason for the differences between the net profit obtained by two logging trucks was that hauling cost was higher in the large-size truck due to loading capacity (Genç and Arıcak, 2016). Besides, total sale price of the forest products hauled from each landing was similar for both logging trucks as sale price is not reflected with the hauling costs. It was found that the highest net profit was received from the forest products hauled from harvesting unit combination of 89 and 91 to landing 2 for both truck types. (Table 16, 17). 

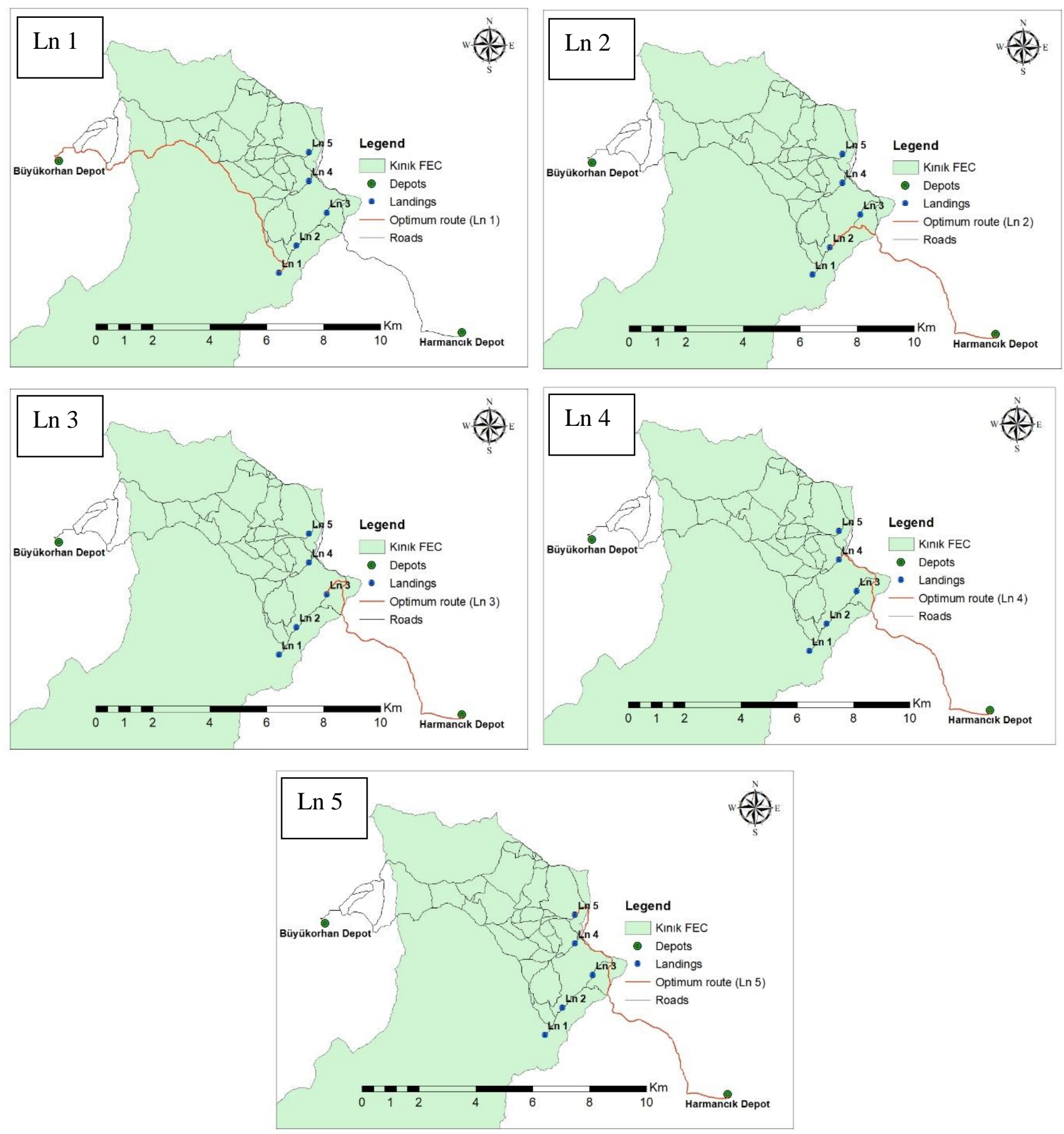

Figure 10. Optimum hauling routes for both logging trucks in the second scenario

Table 15. The summary of total sale price, net profit and hauling cost for the first scenario

\begin{tabular}{ccccccc}
\hline Landing & \multicolumn{3}{c}{ Medium-size truck (TRY) } & \multicolumn{3}{c}{ Large-size truck (TRY) } \\
\cline { 2 - 6 } Areas & Sale Price & Net Profit & Hauling Cost & Sale Price & Net Profit & Hauling Cost \\
\hline Ln 1 & 664894.61 & 637248.88 & 3200.40 & 664894.61 & 637496.15 & 2953.11 \\
Ln 2 & 869122.99 & 828522.78 & 4679.07 & 869122.99 & 828885.65 & 4316.21 \\
Ln 3 & 416348.24 & 394390.18 & 2480.65 & 416348.24 & 394584.83 & 2286.01 \\
Ln 4 & 123180.00 & 118105.97 & 518.46 & 123180.00 & 118147.52 & 476.91 \\
Ln 5 & 585379.88 & 560125.18 & 2098.46 & 585379.88 & 560279.90 & 1943.72 \\
\hline
\end{tabular}


Akay and Şeşen

Table 16. The total net profit of forest products for medium-size truck in the first scenario

\begin{tabular}{cccccc}
\hline Harvesting Units & $\begin{array}{c}\text { Landing } \\
\text { Areas }\end{array}$ & $\begin{array}{c}\text { Log } \\
\text { (TRY) }\end{array}$ & $\begin{array}{c}\text { Mine pole } \\
\text { (TRY) }\end{array}$ & $\begin{array}{c}\text { Industrial wood } \\
\text { (TRY) }\end{array}$ & Paper wood (TRY) \\
\hline 120 & Ln 1 & 430124.00 & 90143.05 & 0.00 & 116981.83 \\
89 and 91 & Ln 2 & 489962.59 & 171109.69 & 6624.54 & 160825.96 \\
64 & Ln 3 & 220348.02 & 142275.47 & 646.31 & 31120.38 \\
38 & Ln 4 & 78130.44 & 26593.87 & 0.00 & 13381.66 \\
25 & Ln 5 & 380631.27 & 91061.97 & 4659.13 & 83772.81 \\
\hline
\end{tabular}

Table 17. The total net profit of forest products for large-size truck in the first scenario

\begin{tabular}{cccccc}
\hline Harvesting Units & $\begin{array}{c}\text { Landing } \\
\text { Areas }\end{array}$ & $\begin{array}{c}\text { Log } \\
(\text { TRY })\end{array}$ & $\begin{array}{c}\text { Mine pole } \\
(\text { TRY })\end{array}$ & $\begin{array}{c}\text { Industrial wood } \\
(\text { TRY })\end{array}$ & Paper wood (TRY) \\
\hline 120 & Ln 1 & 430265.13 & 90185.68 & 0.00 & 117045.34 \\
89 and 91 & Ln 2 & 490137.65 & 171197.92 & 6628.87 & 160921.21 \\
64 & Ln 3 & 220437.49 & 142359.16 & 646.79 & 31141.39 \\
38 & Ln 4 & 78153.87 & 26605.36 & 0.00 & 13388.29 \\
25 & Ln 5 & 380720.61 & 91092.79 & 4661.13 & 83805.37 \\
\hline
\end{tabular}

\subsubsection{Scenario II}

In the second scenario, the optimum transportation plan that maximized the total net profit of forest products was developed for the logging trucks considering both forest depots (Büyükorhan and Harmancık) in the region. The total net profit was estimated as 2573425.88 TRY for the medium-size truck, while it was increased up to 2574378.56 TRY for large-size truck (Table 18). In a study conducted by Eker et al. (2013), it was stated that a total of $13.20 \%$ increase in net profit would be achieved with the hauling plan suggested by Network 2000 program. According to the allocation of forest products using large logging truck, log and paper wood were hauled to Büyükorhan depot, while mine pole and industrial wood were hauled to Harmanckk depot (Table 19, Figure 12).

Table 18. The summary of total sale price, net profit and hauling cost for the second scenario

\begin{tabular}{ccccccc}
\hline \multirow{2}{*}{$\begin{array}{c}\text { Landing } \\
\text { Areas }\end{array}$} & \multicolumn{3}{c}{ Medium-size truck (TRY) } & \multicolumn{3}{c}{ Large-size truck (TRY) } \\
\cline { 2 - 6 } & Sale Price & Net Profit & Hauling Cost & Sale Price & Net Profit & Hauling Cost \\
\hline Ln 1 & 670741.49 & 643019.02 & 3277.14 & 670741.49 & 643274.82 & 3021.34 \\
Ln 2 & 880518.21 & 840083.63 & 4513.43 & 880518.21 & 840429.44 & 4167.62 \\
Ln 3 & 425714.16 & 404167.14 & 2069.62 & 425714.16 & 404328.5 & 1908.26 \\
Ln 4 & 124903.68 & 119878.49 & 469.62 & 124903.68 & 119916.09 & 432.02 \\
Ln 5 & 591474.54 & 566277.6 & 2040.71 & 591474.54 & 566429.71 & 1888.60 \\
\hline
\end{tabular}

Table 19. The hauling destination of the forest products for both trucks in the second scenario

\begin{tabular}{cccccc}
\hline \multirow{2}{*}{$\begin{array}{c}\text { Harvesting } \\
\text { Units }\end{array}$} & \multirow{2}{*}{$\begin{array}{c}\text { Landing } \\
\text { Areas }\end{array}$} & \multicolumn{2}{c}{ Medium-size truck } & \multicolumn{2}{c}{ Large-size truck } \\
\cline { 3 - 5 } & & Büyükorhan D. & Harmancık D. & Büyükorhan D. & Harmancık D. \\
\hline 120 & Ln 1 & L and PW & MP and IW & L and PW & MP and IW \\
89 and 91 & Ln 2 & L, MP and PW & EW & L and PW & MP and IW \\
64 & Ln 3 & L and PW & MP and IW & L and PW & MP and IW \\
38 & Ln 4 & L and PW & MP and IW & L and PW & MP and IW \\
25 & Ln 5 & L and MP & IW and PW & L and PW & MP and IW \\
\hline
\end{tabular}



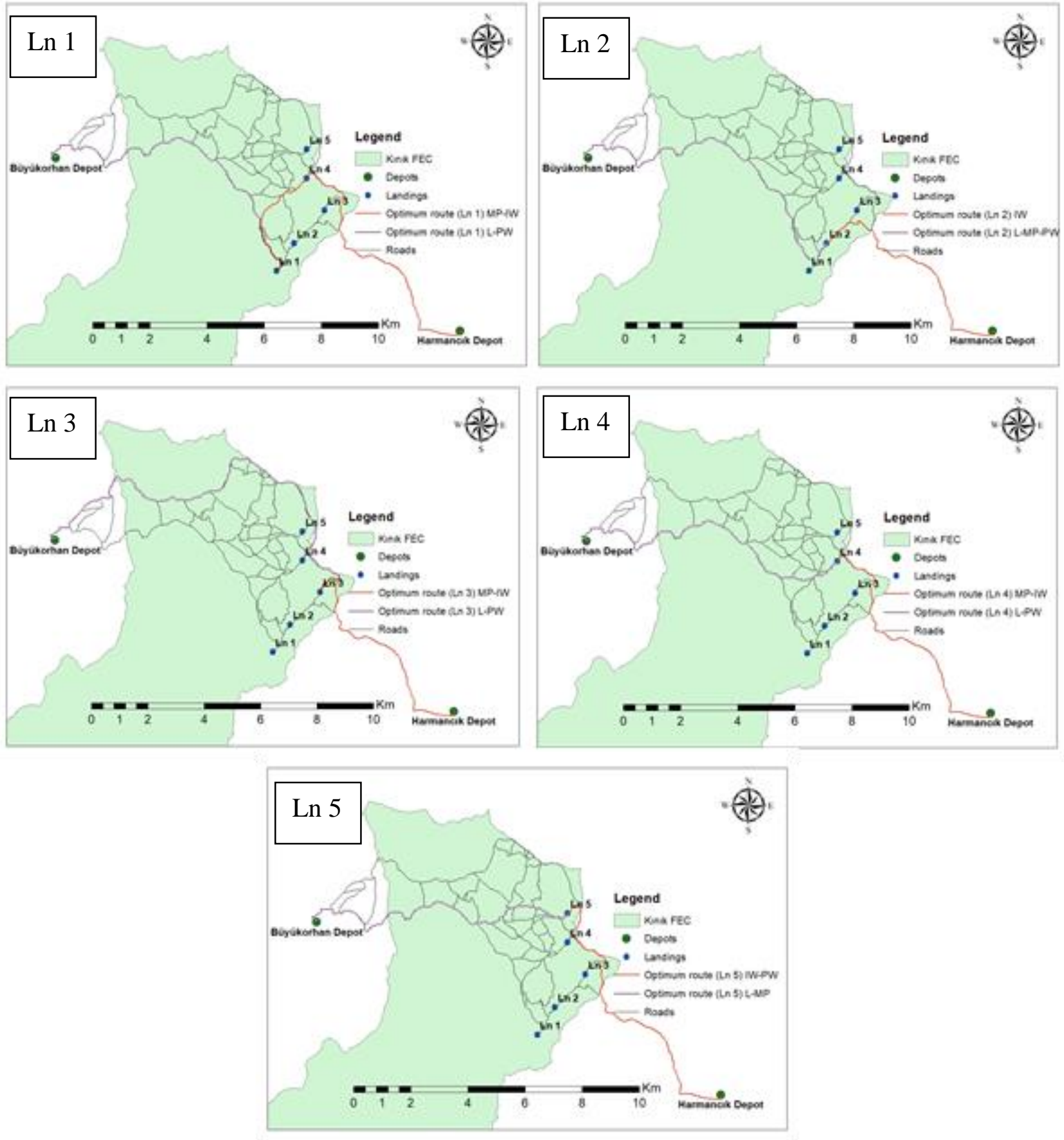

Figure 12. Optimum hauling routes for the large-size logging truck in the second scenario

For the case of medium-size logging truck, the allocation of forest products in landing 1,3 , and 4 was similar as the allocation occurred for the case of large truck (Figure 13). In the landing 2, industrial wood was hauled to Harmancik depot while other products were hauled to Büyükorhan depot. The log and mine pole was hauled to Büyükorhan depot while industrial and paper wood was to Harmancik depot in the landing 5. For the product types, the forest products hauled from harvesting unit combination of 89 and 91 to landing 2 again provided the highest net profit for both truck types (Table 20, 21).

\section{Conclusions}

It is imperative that the hauling of forest products, which constitutes a significant part of the total production cost of forest products, should be planned effectively. The network analysis method is used to evaluate a large number of alternative routes and to systematically search for the most suitable (minimum cost/maximum net profit) alternative. The network analysis-based Network 2000 program, which is effectively used in the transportation planning of forest products, was used to search for optimum transportation 

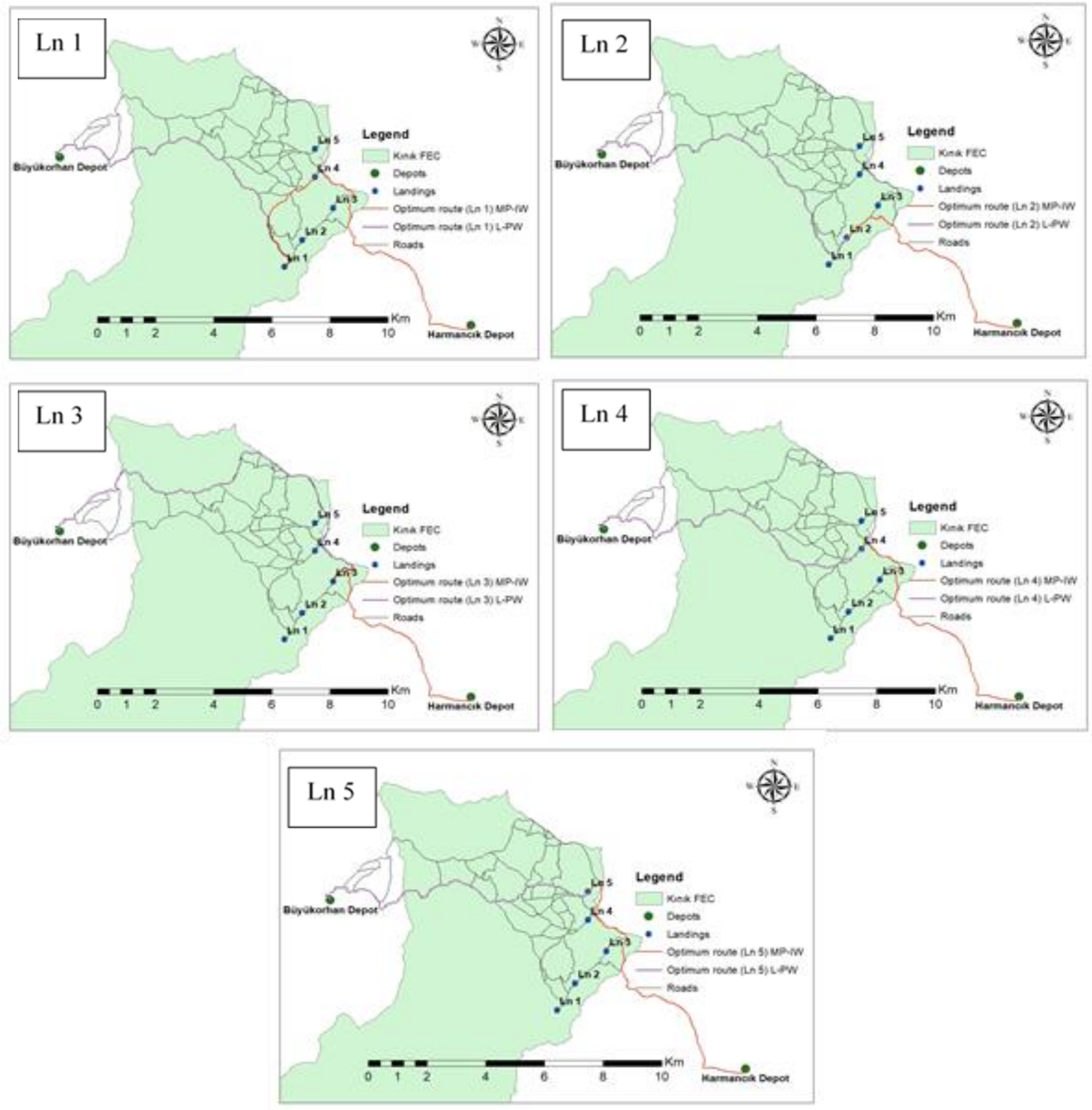

Figure 13. Optimum hauling routes for the medium-size logging truck in the second scenario

Table 20. The total net profit of forest products for medium-size truck in the second scenario

\begin{tabular}{cccccc}
\hline Harvesting Units & $\begin{array}{c}\text { Landing } \\
\text { Areas }\end{array}$ & $\begin{array}{c}\text { Log } \\
(\text { TRY })\end{array}$ & $\begin{array}{c}\text { Mine pole } \\
(\text { TRY })\end{array}$ & $\begin{array}{c}\text { Industrial wood } \\
(\text { TRY })\end{array}$ & Paper wood (TRY) \\
\hline 120 & Ln 1 & 430124.00 & 95913.19 & 0.00 & 116981.83 \\
89 and 91 & Ln 2 & 489962.59 & 182412.22 & 6882.86 & 160825.96 \\
64 & Ln 3 & 220348.02 & 152025.44 & 673.30 & 31120.38 \\
38 & Ln 4 & 78130.44 & 28366.39 & 0.00 & 13381.66 \\
25 & Ln 5 & 380631.27 & 97035.10 & 4838.42 & 83772.81 \\
\hline
\end{tabular}


Table 21. The total net profit of forest products for large-size truck in the second scenario

\begin{tabular}{cccccc}
\hline Harvesting Units & $\begin{array}{c}\text { Landing } \\
\text { Areas }\end{array}$ & $\begin{array}{c}\text { Log } \\
\text { (TRY) }\end{array}$ & $\begin{array}{c}\text { Mine pole } \\
(\text { TRY) }\end{array}$ & $\begin{array}{c}\text { Industrial wood } \\
(\text { TRY) }\end{array}$ & Paper wood (TRY) \\
\hline 120 & Ln 1 & 430265.13 & 95964.35 & 0.00 & 117045.34 \\
89 and 91 & Ln 2 & 490137.65 & 182484.19 & 6886.39 & 160921.21 \\
64 & Ln 3 & 220437.49 & 152076.03 & 673.59 & 31141.39 \\
38 & Ln 4 & 78153.87 & 28373.93 & 0.00 & 13388.29 \\
25 & Ln 5 & 380720.61 & 97063.47 & 4840.26 & 83805.37 \\
\hline
\end{tabular}

planning of forest products, was used to search for optimum transportation plans with minimum cost and maximum net profit. Besides, planning of skidding and loading operation was integrated into the solution process. The results indicated that loading capacity of the logging trucks play important role in reducing hauling cost. Besides, integrating alternative forest depots into the transportation plan can help reducing the total cost of forest transportation while increasing the total net profit of the forest products. In regions where intensive forest operations are implemented, using network analysis based methods in developing forest transportation plans will optimize the total net profit and provide significant savings. In the future studies, the Network 2000 program can be used to the plan new forest roads and determine the most suitable routes considering total road construction, maintenance, and transportation costs.

\section{Ethics Committee Approval: N/A.}

Peer-review: Externally peer-reviewed.

Author Contributions: Concept: A.E.A.; Design: A.E.A. and N.Ş.; Supervision: A.E.A.; Resources: N.Ş.; Data Collection: N.Ş.; Analysis: A.E.A. and N.Ş.; Literature Search: N.Ş.; Writing Manuscript: A.E.A.; Critical Review: A.E.A.

Conflict of Interest: The authors have no conflicts of interest to declare.

Financial Disclosure: The authors declared that this study has received no financial support

Cite this paper as: Akay, A.E., Şeşen, N., 2021. Integrated Planning of Timber Extraction and Hauling Activities by using Network 2000 Program, European Journal of Forest Engineering, 7(2):77-91.

\section{References}

Acar, H.H. 1998. Minimization to be using of transport model of transportation costs by trucks at Artvin Forest District, Journal of Agriculture and Forestry, 22(2):491-497.

Acar, H.H., Eroğlu H. 2001. The planning of wood transport on the forest roads, Kafkas University, Artvin Faculty of Forestry Journal, 2(1):61-66.
Akay, A.E., Erdaş, O. 2007. Planning Transportation of Forest Products by Network Model, İstanbul University Faculty of Forestry Journal, 57(2):1-20.

Akay, A.E. Serin, H., Sessions, J., Bilici, E., Pak, M. 2021. Evaluating the Effects of Improving Forest Road Standards on Economic Value of Forest Products. Croatian Journal of Forest Engineering. 42(2):245-258.

Chung, W., Sessions, J. 2001. Network 2001Transportation Planning Under Multiple Objectives, The International Mountain Logging and 11th Pacific Northwest Skyline Symposium, December.

Coşkun, K., Eroğlu, H., Özkaya, M.S., Çetiner K., Bilgin F. 2010. An assessment in terms of mechanization of timber harvesting operations in artvin forest regional directorate, III National Blacksea Forestry Congress, 20-22 May, Volume II, 587-597.

Eker, M., Acar, H.H. 2006. Development of annual operational planning model for timber harvesting, SDÜ Journal of the Graduate School of Natural and Applied Sciences. 10-2:235-248.

Eker, R., Aydın A., Akay A.E. 2013. Optimization of Timber Transportation with Network Approach: A Case Study from Aladag Forest Enterprise. International Caucasian Forestry Symposium. Artvin Çoruh University, Faculty of Forestry, 24-26 October, Artvin. 450-455.

Genç, Ç.Ö., Arıcak, B. 2016. Determination of Routes as Type-A Forest Roads for Long Haulage Vehicles: Küre Forest SubDistrict Directorate, Kastamonu University, Faculty of Forestry Journal, 16(2): 474484.

Sessions, J., Chung, W., Heinimann, H., R. 2001. New Algorithms for Solving Large Scale Harvesting and Transportation Problems Including Environmental Constraints, in Proc. of the FAO/ECE/ILO Workshop on New Trends in Wood Harvesting with Cable Systems for Sustainable Forest Management in Mountain Forests, Ossiach, Austria, June 18-24. 